benzene was stirred for 3 days at room temperature. The benzene solvent was removed in vacuo. The oily residue was stirred with $25 \mathrm{~mL}$ of pentane. The yellow product was collected by filtration and dried in vacuo: yield $0.2 \mathrm{~g}(20 \%) ; \mathrm{mp} 141{ }^{\circ} \mathrm{C} ;{ }^{1} \mathrm{H}$ NMR $\left(\mathrm{C}_{7} \mathrm{D}_{8}\right.$, $400 \mathrm{MHz}, 203 \mathrm{~K}$ ). At low temperature the spectra of the isomeric complexes $10 \mathrm{~d}$ and $13 \mathrm{a}$ have been observed in a $45: 55$ ratio. $10 \mathrm{~d}$ : $\delta 1.38(\mathrm{~s}, 18 \mathrm{H}, t-\mathrm{BuCp}), 2.57\left(\mathrm{~s}, 3 \mathrm{H}, \mathrm{CH}_{3}\right), 2.61\left(\mathrm{~s}, 3 \mathrm{H}, \mathrm{CH}_{3}\right)$, 4.76 (br s, $4 \mathrm{H}, t$-BuCp), 5.14 (br s, $4 \mathrm{H}, t-\mathrm{BuCp}$ ), 5.25 (s, $10 \mathrm{H}$, $\mathrm{Cp}) .13 \mathrm{a}: \delta 1.44(\mathrm{~s}, 18 \mathrm{H}, t-\mathrm{BuCp}), 2.67\left(\mathrm{~s}, 6 \mathrm{H}, \mathrm{CH}_{3}\right), 5.00(\mathrm{~s}$, $10 \mathrm{H}, \mathrm{Cp}$ ), 5.21 (br s, $4 \mathrm{H}, t-\mathrm{BuCp}$ ), 5.45 (br s, $4 \mathrm{H}, t$-BuCp); estimation of the activation barrier of the $10 \mathrm{~d} \rightleftharpoons 13 \mathrm{a}$ rearrangement from the $\mathrm{Cp}$ coalescence $(80 \mathrm{MHz}), \Delta v(208 \mathrm{~K})=18.5$ $\pm 0.5 \mathrm{~Hz}, \Delta G^{*}(218 \mathrm{~K})=12.6 \pm 0.5 \mathrm{kcal} / \mathrm{mol} ;{ }^{13} \mathrm{C} \mathrm{NMR:} 10 \mathrm{~d}, \delta$ $17.1\left(\mathrm{q},{ }^{1} J_{\mathrm{CH}}=128 \mathrm{~Hz}, \mathrm{CH}_{3}\right), 19.1\left(\mathrm{q},{ }^{1} J_{\mathrm{CH}}=127 \mathrm{~Hz}, \mathrm{CH}_{3}\right), 32.3$ $\left(\mathrm{q},{ }^{1} J_{\mathrm{c}_{\mathrm{H}}}=125 \mathrm{~Hz}, t-\mathrm{BuCp}\right), 32.5(\mathrm{~s}, t-\mathrm{BuCp}), 102.4\left(\mathrm{~d},{ }^{1} J_{\mathrm{CH}}=\right.$ $169 \mathrm{~Hz}, \mathrm{Cp}), 132.7$ (s, $t$-BuCp), 146.3 (s, C2), 149.8 (s, C2'), 204.1 (s, C1), $208.5\left(\mathrm{~s}, \mathrm{C}^{\prime}\right) ; 13 \mathrm{a}, \delta 18.6\left(\mathrm{q},{ }^{1} J_{\mathrm{CH}}=128 \mathrm{~Hz}, \mathrm{CH}_{3}\right), 31.7$ $(\mathrm{s}, t-\mathrm{BuCp}), 32.8\left(\mathrm{q},{ }^{1} J_{\mathrm{CH}}=125 \mathrm{~Hz}, t-\mathrm{BuCp}\right), 103.9\left(\mathrm{~d},{ }^{1} J_{\mathrm{CH}}=169\right.$ $\mathrm{Hz}, \mathrm{Cp}), 133.2(\mathrm{~s}, t-\mathrm{BuCp}), 142.1\left(\mathrm{C} 2, J_{\mathrm{CH}}=8.0 \mathrm{~Hz}\right), 178.1(\mathrm{C} 1$, $\left.J_{\mathrm{CH}}=4.4 \mathrm{~Hz}\right) ; \mathrm{IR}(\mathrm{KBr}) 1870(\mathrm{w}) ; 1815(\mathrm{~m})(\mathrm{C} \equiv \mathrm{C}) \mathrm{cm}^{-1} ; \mathrm{MS}\left(\mathrm{M}^{+}\right)$ $m / e$ 630. Anal. Calcd for $\mathrm{C}_{34} \mathrm{H}_{42} \mathrm{Zr}_{2}: \mathrm{C}, 64.50 ; \mathrm{H}, 6.69$. Found: C, $64.60 ; \mathrm{H}, 6.67$.

Photolysis of Dipropynylbis ( $\eta$-tert-butylcyclopentadienyl)zirconium (6c) in the Presence of Zirconocene Dicarbonyl at Low Temperature. A solution containing 60 $\mathrm{mg}(0.14 \mathrm{mmol})$ of dipropynylbis $(\eta$-tert-butylcyclopentadienyl)zirconium (6c) and $40 \mathrm{mg}(0.14 \mathrm{mmol})$ of zirconocene dicarbonyl in $0.4 \mathrm{~mL}$ of toluene- $d_{8}$ was irradiated for $40 \mathrm{~min}$ at $-40^{\circ} \mathrm{C}$ (HPK 125, Pyrex filter). The solution was then directly analyzed by ${ }^{1} \mathrm{H}$ NMR spectroscopy at $-40^{\circ} \mathrm{C}$. Formation of $10 \mathrm{~d} / 13 \mathrm{a}$ as the only reaction products was observed at about $20 \%$ conversion rate, achieved under these conditions. No further reaction products or intermediates were found.

Reaction of Dipropynylzirconocene (6a) with (Butadiene)bis ( $\eta$-tert -butylcyclopentadienyl) zirconium. A mixture

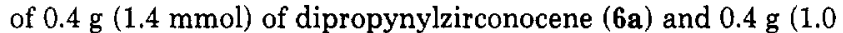
$\mathrm{mmol}$ ) of (butadiene)bis ( $\eta$-tert-butylcyclopentadienyl)zirconium in $10 \mathrm{~mL}$ of toluene was stirred for several days at room temperature. The progress of the reaction was followed by ${ }^{1} \mathrm{H} N M R$ spectroscopy. After 12 days, most of the dipropynylzirconocene starting material had been consumed, while there was still some unused butadiene metallocene reagent around. In addition to the unsymmetrically substituted binuclear product $10 \mathrm{~d} / 13 \mathrm{a}$ some $\left[\mathrm{Cp}_{2} \mathrm{Zr}\right]_{2}\left(\mu-\mathrm{C}=\mathrm{CCH}_{3}\right)_{2}(\mathbf{1 0 a})$ was formed (ratio $\left.3: 1\right)$.

Acknowledgment. Generous financial aid from the Deutsche Forschungsgemeinschaft, the Fonds der Chemischen Industrie, and the Alfried Krupp von Bohlen und Halbach-Stiftung (grants to G.E.) is gratefully acknowledged. W.F. wishes to thank the Max-Planck-Gesellschaft for a Stipendium.

Registry No. 6a, 103111-51-9; 6b, 105036-32-6; 6c, 119071-19-1; 6d, 72982-57-1; 6e, 72951-38-3; 6f, 119071-20-4; 6g, 119071-21-5; 6h, 84879-48-1; 7a, 119071-22-6; 7b, 119071-22-6; 7c, 119071-23-7; 7d, 119071-24-8; 9a, 119071-25-9; 9b, 119071-27-1; 9c, 119071-26-0; 9d, 119071-28-2; 10a, 119108-44-0; 10b, 119108-46-2; 10c, 119144-91-1; 10d, 119144-92-2; 10e, 119108-47-3; 10f, 101518-71-2; 10g, 119108-48-4; 10h, 119108-45-1; 13a, 119108-49-5; zirconocene dichloride, 1291-32-3; propynyllithium, 4529-04-8; bis $(\eta$ methylcyclopentadienyl)zirconium dichloride, 12109-71-6; bis ( $\eta$ tert-butylcyclopentadienyl)zirconium dichloride, 32876-92-9; sodium phenylacetylide, 1004-22-4; hafnocene dichloride, 12116-66-4; (butadiene)zirconocene, 75374-50-4; (butadiene)bis ( $\eta$-methylcyclopentadienyl)zirconium, 101518-70-1; zirconocene dicarbonyl, 59487-85-3; (butadiene) bis ( $\eta$-tert-butylcyclopentadienyl)zirconium, 113667-86-0.

Supplementary Material Available: Detailed information on the crystal structure determination of 6 a including tables of atomic thermal parameters, atom coordinates, and interatomic distances and angles (6 pages); a listing of structure factors for $6 a$ (5 pages). Ordering information is given on any current masthead page.

\title{
Synthesis and Crystal Structure of the New Mixed-Metal, Mixed-Ligand Cluster Compound $\mathrm{Zn}_{4} \mathrm{Ni}_{2}\left(\mathrm{C}_{5} \mathrm{H}_{5}\right)_{4}\left(\mathrm{C}_{5} \mathrm{Me}_{5}\right)_{2}$
}

\author{
Bart Fischer, Henk Kleijn, Jaap Boersma, ${ }^{*}$ and Gerard van Koten \\ Department of Metal-mediated Synthesis, Laboratory for Organic Chemistry, University of Utrecht, Padualaan 8 ,
} $3584 \mathrm{CH}$ Utrecht, The Netherlands

Anthony L. Spek

Vakgroep Algemene Chemie, afdeling Kristal- en Structuurchemie, University of Utrecht, Padualaan 8 , $3584 \mathrm{CH}$ Utrecht, The Netherlands

Received July 18, 1988

\begin{abstract}
The reaction of equimolar amounts of $\mathrm{Zn}\left(\mathrm{C}_{5} \mathrm{H}_{5}\right)_{2}, \mathrm{Zn}\left(\mathrm{C}_{5} \mathrm{Me}_{5}\right)_{2}$, and $\mathrm{Ni}(\mathrm{COD})_{2}$ afforded the zinc-containing mixed-metal, mixed-ligand cluster compound $\mathrm{Zn}_{4} \mathrm{Ni}_{2}\left(\mathrm{C}_{5} \mathrm{H}_{5}\right)_{4}\left(\mathrm{C}_{5} \mathrm{Me}_{5}\right)_{2}$. Crystals of the title compound are monoclinic, space group $P 2_{1} / n$, with unit-cell dimensions $a=10.87$ (1) $\AA, b=14.86$ (1) $\AA, c=11.60$ (1) $\AA, \beta=96.12(5)^{\circ}$, and $Z=2$. The structure refinement converged at $R_{F}=0.063$. The cluster $Z_{n_{4}} \mathrm{Ni}_{2^{-}}$ $\left(\mathrm{C}_{5} \mathrm{H}_{5}\right)_{4}\left(\mathrm{C}_{5} \mathrm{Me}_{5}\right)_{2}$ is the first characterized example of a metal complex containing an isolated, $\eta^{2}$-coordinating, main-group metal bonded cyclopentadienyl ring, in this case a pentamethyl-substituted one. The unsubstituted rings are bonded to zinc and nickel in an $\eta^{2}-\eta^{3}$ and $\eta^{5}$ mode, respectively. This compound has provided further support for the previously proposed mechanism for the formation of related ZnNi clusters, and the selectivity of the reaction has enabled us to identify the rate-determining step in these cluster-forming reactions. The surprisingly high yield, compared to that of $\mathrm{Zn}_{4} \mathrm{Ni}_{2}\left(\mathrm{C}_{5} \mathrm{H}_{5}\right)_{6}$, with which the new cluster is formed can be explained by assuming a stabilizing influence of the pentamethylcyclopentadienyl ligand on the key-trimetallic radical intermediate. Zinc-bonded cyclopentadienyl rings easily adapt to steric interference by changing their hapticity. This occurs in particular when their size increases through the introduction of substituents and is in accord with the largely ionic character of the zinc-cyclopentadienyl interaction.
\end{abstract}

Introduction

Recently, we reported the preparation and crystal structure determination of the first zinc-nickel cluster compound $\mathrm{Zn}_{4} \mathrm{Ni}_{2}\left(\mathrm{C}_{5} \mathrm{H}_{5}\right)_{6}$ which was obtained from the reaction of dicyclopentadienylzinc with bis(1,4-cyclooctadiene)nickel $\left[\mathrm{Ni}(\mathrm{COD})_{2}\right]{ }^{1}$ The fact that this heter- 


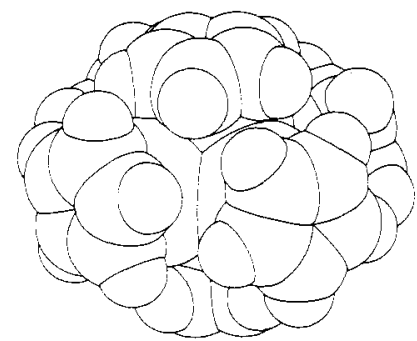

Figure 1. Space-filling model of the cluster compound $\mathrm{Zn}_{4^{-}}$ $\mathrm{Ni}_{2}\left(\mathrm{C}_{5} \mathrm{H}_{5}\right)_{6}$, showing the shielding of the metal core by the cyclopentadienyl ligands.

onuclear cluster contains metals with complementary properties, i.e. zinc as an acidic site and nickel as a site for coordination of alkenes and alkynes, prompted us to start a study of the possible use of these clusters as catalysts. $\mathrm{Zn}_{4} \mathrm{Ni}_{2}\left(\mathrm{C}_{5} \mathrm{H}_{5}\right)_{6}$, however, did not show any activity toward molecules containing a heteroatom and a double or triple bond, e.g. methoxybutyne and methylpropargylic ether. This is probably related to its very compact structure in which the cyclopentadienyl ligands completely shield the metal core. A space-filling model (see Figure 1) shows this clearly.

It was thought that the introduction of substituents on the cyclopentadienyl rings might lead to more open, more reactive clusters through either deshielding of the metal core or stabilization of reaction intermediates caused by steric interference of the substituents.

It was found that reaction of $\mathrm{Ni}(\mathrm{COD})_{2}$ with zinc compounds $\mathrm{Zn}\left(\mathrm{C}_{5} \mathrm{H}_{4} \mathrm{R}\right)_{2}\left(\mathrm{R}=\mathrm{Me}, t-\mathrm{Bu}, \mathrm{SiMe}_{3}\right)$ also resulted in clusters with $\mathrm{Zn}_{4} \mathrm{Ni}_{2}\left(\mathrm{C}_{5} \mathrm{H}_{4} \mathrm{R}\right)_{6}$ stoichiometry, ${ }^{2}$ though the reaction of the permethyl derivative $\mathrm{Zn}\left(\mathrm{C}_{5} \mathrm{Me}_{5}\right)_{2}$ with $\mathrm{Ni}(\mathrm{COD})_{2}$ yielded a zinc-free, dinickel complex $\left[\left(\mathrm{C}_{5} \mathrm{Me}_{5}\right) \mathrm{NiC}_{8} \mathrm{H}_{12}\right]_{2}{ }^{3}$

The introduction of large substituents in $\mathrm{Zn}_{4} \mathrm{Ni}_{2}\left(\mathrm{C}_{5} \mathrm{H}_{4} \mathrm{R}\right)_{6}$ does indeed cause an unprecedented change in the hapticity of the cyclopentadienyl rings. In $\mathrm{Zn}_{4} \mathrm{Ni}_{2}\left(\mathrm{C}_{5} \mathrm{H}_{5}\right)_{6}$ all cyclopentadienyl rings are $\eta^{5}$-bonded while in $\mathrm{Zn}_{4} \mathrm{Ni}_{2}$ $\left(\mathrm{C}_{5} \mathrm{H}_{4} \text {-t-Bu }\right)_{6}$ two zinc-bonded cyclopentadienyl ligands have changed to $\eta^{1}$-coordination and in $\mathrm{Zn}_{4} \mathrm{Ni}_{2}-$ $\left(\mathrm{C}_{5} \mathrm{H}_{4} \mathrm{SiMe}_{3}\right)_{6}$ three different hapticities occur, i.e. two $\eta^{5}$ to nickel, two $\eta^{3}$ to zinc, and two $\eta^{1}$ to zinc.

In order to gain more insight into the role of the $R$ substituents in the cluster formation mechanism, we have prepared the mixed-metal, mixed-ligand cluster $\mathrm{Zn}_{4} \mathrm{Ni}_{2}$ $\left(\mathrm{C}_{5} \mathrm{H}_{5}\right)_{4}\left(\mathrm{C}_{5} \mathrm{Me}_{5}\right)_{2}$. Its synthesis and crystal structure provided further support for the earlier proposed mechanism ${ }^{2,3}$ by which these $\mathrm{Zn}_{4} \mathrm{Ni}_{2}$ clusters are formed and allowed us to determined the rate-determining step in the clusterformation reaction.

\section{Experimental Section}

All experiments were carried out in an atmosphere of dry, oxygen-free nitrogen by using standard Schlenk techniques. Solvents were dried and distilled from sodium benzophenone ketyl prior to use. NMR spectra were recorded on a Bruker AC 200P spectrometer.

$\mathrm{Zn}\left(\mathrm{C}_{5} \mathrm{H}_{5}\right)_{2}$ and $\mathrm{Zn}\left(\mathrm{C}_{5} \mathrm{Me}_{5}\right)_{2}$ were prepared by methods published earlier. ${ }^{4} \mathrm{Ni}(\mathrm{COD})_{2}$ was prepared by a modification of the pro-

(1) (a) Budzelaar, P. H. M.; Boersma, J.; van der Kerk, G. J. M. Angew. Chem., Int. Ed. Engl. 1985, 22, 329. (b) Budzelaar, P. H. M.; Boersma, J.; van der Kerk, G. J. M.; Spek, A. L.; Duisenberg, A. J. M. Organometallics 1985, 4, 686 .

(2) Fischer, B.; Boersma, J.; van Koten, G.; Spek, A. L. New. J. Chem. $1988,12,613$.

(3) Fischer, B.; Boersma, J.; Kojič-Prodič, B.; Spek, A. L. J. Chem. Soc., Chem. Commun. 1985, 1237.
Table I. Crystal Data and Details of the Structure Determination

\begin{tabular}{|c|c|}
\hline \multicolumn{2}{|c|}{ a) Crystal Data } \\
\hline formula & $\mathrm{C}_{40} \mathrm{H}_{50} \mathrm{Ni}_{2} \mathrm{Zn}_{4}$ \\
\hline $\mathrm{mol} \mathrm{wt}$ & 909.73 \\
\hline cryst system & monoclinic \\
\hline space group & $P 2_{1} / \mathrm{n}$ \\
\hline$a, \AA$ & $10.87(1)$ \\
\hline$b, \AA$ & $14.86(1)$ \\
\hline$c, \AA$ & 11.60 (1) \\
\hline$\beta, \operatorname{deg}$ & $96.12(5)$ \\
\hline$V, \AA^{3}$ & $1863(3)$ \\
\hline$Z$ & 2 \\
\hline$D_{\text {calcd }}, \mathrm{g} \mathrm{cm}^{-3}$ & 1.622 \\
\hline$F(000)$, electrons & 932 \\
\hline$\mu(\mathrm{Mo} \mathrm{K} \alpha), \mathrm{cm}^{-1}$ & 36.2 \\
\hline cryst size, mm & $0.22 \times 0.25 \times 0.28$ \\
\hline
\end{tabular}

\begin{tabular}{ll} 
& (b) Data Collection \\
radiatn & $\mathrm{Zr}$-filtered Mo $\mathrm{K} \alpha, \lambda=0.71073 \AA$ \\
$\theta_{\min }, \theta_{\max }$, deg & $1.22,25.0$ \\
$\omega$-scan, deg & $\Delta \omega=0.55+0.35 \tan \theta$ \\
hor and vert apert, $\mathrm{mm}$ & 3,3 \\
data set $(h, k, l)$ & -17 to $+17,0$ to 17,0 to 19 \\
ref reflctns & $-1,1,2 ;-1,-2,-1 ; 0,-1,1$ \\
total data, unique data & 3413,3266 \\
obsd data $(I>2 \sigma(I))$ & 1828 \\
\multicolumn{3}{c}{ (c) Refinement } \\
no. of refined parameters & 211 \\
weighting scheme & $w^{-1}=\sigma^{2}(F)+0.00073 F^{2}$ \\
$R$, w $R, S$ & $0.063,0.068,2.5$ \\
min and max resid density, $\mathrm{e} / \AA^{3}$ & $-0.63,0.83$ \\
$(\Delta / \sigma)_{\mathrm{av}},(\Delta / \sigma)_{\max }$ & $0.1,0.6$
\end{tabular}

cedure published by Brauer. ${ }^{5}$

$\mathrm{Zn}_{4} \mathrm{Ni}_{2}\left(\mathrm{C}_{5} \mathrm{H}_{5}\right)_{4}\left(\mathrm{C}_{5} \mathrm{Me}_{5}\right)_{2}$. (a) Reaction with Initial RoomTemperature Stirring. A suspension of $2.06 \mathrm{~g}(10.5 \mathrm{mmol})$ of $\mathrm{Zn}\left(\mathrm{C}_{5} \mathrm{H}_{5}\right)_{2}, 3.50 \mathrm{~g}(10.4 \mathrm{mmol})$ of $\mathrm{Zn}\left(\mathrm{C}_{5} \mathrm{Me}_{5}\right)_{2}$, and $2.89 \mathrm{~g}(10.5$ $\mathrm{mmol}$ ) of $\mathrm{Ni}(\mathrm{COD})_{2}$ in $100 \mathrm{~mL}$ of benzene was stirred for $24 \mathrm{~h}$ at room temperature, after which the temperature was gradually raised to $70^{\circ} \mathrm{C}$. After $5 \mathrm{~h}$ at $70^{\circ} \mathrm{C}$ no more $\mathrm{Ni}(\mathrm{COD})_{2}$ could be detected by ${ }^{1} \mathrm{H}$ NMR spectroscopy. The benzene solution was evaporated to dryness in vacuo and the residue washed twice with $50 \mathrm{~mL}$ of pentane and then extracted three times with $25 \mathrm{~mL}$ of THF. Evaporation to dryness in vacuo of the THF extracts yielded $3.53 \mathrm{~g}$ (3.89 mmol) of pure, dark green $\mathrm{Zn}_{4} \mathrm{Ni}_{2}\left(\mathrm{C}_{5} \mathrm{H}_{5}\right)_{4}$. $\left(\mathrm{C}_{5} \mathrm{Me}_{5}\right)_{2}\left(74 \%\right.$, based on $\left.\mathrm{Ni}(\mathrm{COD})_{2}\right)$. ${ }^{1} \mathrm{H} \mathrm{NMR}\left(200 \mathrm{MHz}, \mathrm{CDCl}_{3}\right)$ : $\delta 6.35(\mathrm{~s}, 10 \mathrm{H}), 4.93(\mathrm{~s}, 10 \mathrm{H}), 2.15(\mathrm{~s}, 30 \mathrm{H}) .{ }^{13} \mathrm{C}$ NMR $(50.32$ $\left.\mathrm{MHz}_{2} \mathrm{CDCl}_{3}\right): \delta 114.12,106.60,85.26,11.69$. Elemental Anal. Calcd (Found): C, 52.80 (52.50); H, 5.50 (5.61); Ni, 12.9 (12.8); $\mathrm{Zn}, 28.8$ (29.1).

Single crystals were obtained by slow cooling of a warm, saturated benzene solution.

(b) Reaction without Initial Room-Temperature Stirring. A suspension of $1.99 \mathrm{~g}(10.2 \mathrm{mmol})$ of $\mathrm{Zn}\left(\mathrm{C}_{5} \mathrm{H}_{5}\right)_{2}, 3.46 \mathrm{~g}(10.3 \mathrm{mmol})$ of $\mathrm{Zn}\left(\mathrm{C}_{5} \mathrm{Me}_{5}\right)_{2}$, and $2.80 \mathrm{~g}(10.2 \mathrm{mmol})$ of $\mathrm{Ni}(\mathrm{COD})_{2}$ in $100 \mathrm{~mL}$ of benzene was stirred for $7 \mathrm{~h}$ at $70^{\circ} \mathrm{C}$. The resulting dark green solution was evaporated to dryness in vacuo and the residue washed twice with $50 \mathrm{~mL}$ of pentane and then extracted three times with $25 \mathrm{~mL}$ of THF. Evaporation to dryness in vacuo of the THF extracts yielded $3.31 \mathrm{~g}(3.89 \mathrm{mmol})$ of solid, dark green material, the composition of which was determined by ${ }^{1} \mathrm{H}$ NMR spectroscopy to be $30 \%$ of $\mathrm{Zn}_{4} \mathrm{Ni}_{2}\left(\mathrm{C}_{5} \mathrm{H}_{5}\right)_{6}$ and $70 \%$ of $\mathrm{Zn}_{4} \mathrm{Ni}_{2}$ $\left(\mathrm{C}_{5} \mathrm{H}_{5}\right)_{4}\left(\mathrm{C}_{5} \mathrm{Me}_{5}\right)_{2}$, which adds up to an overal yield of $75 \%$ based on $\mathrm{Ni}(\mathrm{COD})_{2}$.

Structure Determination and Refinement. Crystal data and numerical details of the structure determination are presented in Table I. X-ray data were collected on an Enraf-Nonius CAD4F diffractometer for a dark green octahedral crystal mounted under nitrogen in a Lindemann glass capillary. Unit cell parameters

(4) (a) Budzelaar, P. H. M.; Boersma, J.; van der Kerk, G. J. M.; Spek A. L.; Duisenberg, A. J. M. J. Organomet. Chem. 1985, 281, 123. (b) Blom, R.; Boersma, J.; Budzelaar, P. H. M.; Fischer, B.; Haaland, A.; Volden, H. V.; Weidlein, W. Acta Chem. Scand. 1986, A40, 113.

(5) Brauer, G. Handbuch der präparativen Anorganische Chemie, 3rd ed.; Ferdinant Enke Verlag: Stuttgart, 1981; Vol. 3, p 1897. 
Scheme I. Influence of the Reaction Conditions on the Product Formation in the Cluster-Forming Reaction

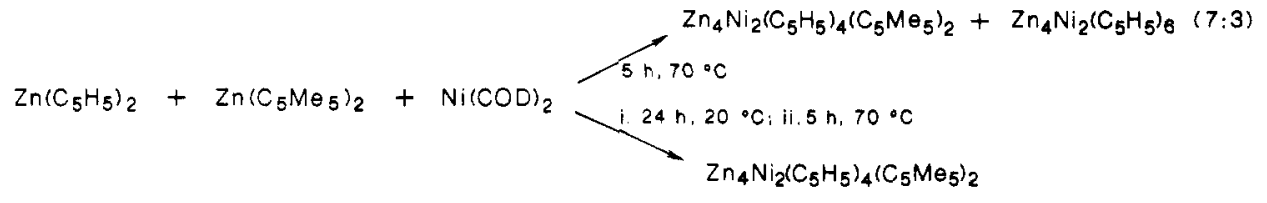

Table II. Positional and Equivalent Isotropic Thermal Parameters for $\mathrm{Zn}_{4} \mathrm{Ni}_{2}\left(\mathrm{C}_{5} \mathrm{H}_{5}\right)_{4}\left(\mathrm{C}_{5} \mathrm{Me}_{5}\right)_{2}{ }^{a}$

\begin{tabular}{lllll}
\hline atom & \multicolumn{1}{c}{$x$} & \multicolumn{1}{c}{$y$} & \multicolumn{1}{c}{$z$} & $U(\mathrm{eq}), \AA^{2}$ \\
\hline $\mathrm{Zn}(1)$ & $0.4401(1)$ & $0.4559(1)$ & $0.1505(1)$ & $0.0678(5)$ \\
$\mathrm{Zn}(2)$ & $0.6038(1)$ & $0.5975(1)$ & $0.0910(1)$ & $0.0589(5)$ \\
$\mathrm{Ni}$ & $0.5943(1)$ & $0.4484(1)$ & $0.0133(1)$ & $0.0463(4)$ \\
$\mathrm{C}(1)$ & $0.669(2)$ & $0.338(1)$ & $0.111(2)$ & $0.094(7)$ \\
$\mathrm{C}(2)$ & $0.664(1)$ & $0.3182(9)$ & $-0.009(2)$ & $0.087(6)$ \\
$\mathrm{C}(3)$ & $0.736(2)$ & $0.380(1)$ & $-0.060(2)$ & $0.099(7)$ \\
$\mathrm{C}(4)$ & $0.784(1)$ & $0.437(1)$ & $0.028(2)$ & $0.102(8)$ \\
$\mathrm{C}(5)$ & $0.744(2)$ & $0.411(1)$ & $0.129(1)$ & $0.098(7)$ \\
$\mathrm{C}(6)$ & $0.740(2)$ & $0.6392(9)$ & $0.278(1)$ & $0.078(6)$ \\
$\mathrm{C}(7)$ & $0.837(1)$ & $0.636(1)$ & $0.212(1)$ & $0.083(6)$ \\
$\mathrm{C}(8)$ & $0.809(1)$ & $0.687(1)$ & $0.115(1)$ & $0.082(6)$ \\
$\mathrm{C}(9)$ & $0.695(2)$ & $0.7321(8)$ & $0.120(1)$ & $0.080(6)$ \\
$\mathrm{C}(10)$ & $0.650(1)$ & $0.6976(9)$ & $0.226(1)$ & $0.068(5)$ \\
$\mathrm{C}(11)$ & $0.736(2)$ & $0.593(1)$ & $0.392(1)$ & $0.137(8)$ \\
$\mathrm{C}(12)$ & $0.958(2)$ & $0.585(1)$ & $0.241(2)$ & $0.142(9)$ \\
$\mathrm{C}(13)$ & $0.892(2)$ & $0.703(1)$ & $0.019(1)$ & $0.19(1)$ \\
$\mathrm{C}(14)$ & $0.645(2)$ & $0.808(1)$ & $0.049(1)$ & $0.162(9)$ \\
$\mathrm{C}(15)$ & $0.543(1)$ & $0.734(1)$ & $0.283(2)$ & $0.145(9)$ \\
$\mathrm{C}(16)$ & $0.265(3)$ & $0.394(2)$ & $0.254(2)$ & $0.26(2)$ \\
$\mathrm{C}(17)$ & $0.278(2)$ & $0.467(2)$ & $0.308(2)$ & $0.16(1)$ \\
$\mathrm{C}(18)$ & $0.393(3)$ & $0.488(2)$ & $0.351(2)$ & $0.14(1)$ \\
$\mathrm{C}(19)$ & $0.460(2)$ & $0.418(2)$ & $0.336(2)$ & $0.120(9)$ \\
$\mathrm{C}(20)$ & $0.379(3)$ & $0.358(1)$ & $0.277(2)$ & $0.15(1)$ \\
${ }^{\prime} U_{\text {eq }}=1 / 3 \sum_{i} \sum_{j} U_{i j} a_{i}^{*}{ }^{*} a_{j}^{*} \mathbf{a}_{i} \cdot \mathbf{a}_{j}$. & &
\end{tabular}

were derived by least squares from the diffractometer settings of 22 reflections in the range $18 \leq 2 \theta \leq 24^{\circ} .{ }^{6}$ The space group was derived from the observed systematic extinctions. Three reference reflections showed a small decay of $1 \%$ over the $88 \mathrm{~h}$ of X-ray exposure time. Data were corrected for $L p$, the small decay, and for absorption with the program DIFABS (minimum and maximum correction 0.70 and 1.22 , respectively). ${ }^{7}$ The structure was solved by direct methods with the program SHELXS $86^{8}$ and refined on $\mathrm{F}$ by full-matrix least-squares on a MicroVAX-II with SHELX $76 .{ }^{9}$ Hydrogen atoms were introduced at calculated positions $(\mathrm{C}-\mathrm{H}=1.08 \AA$ ) and refined with fixed geometry with respect to their carrier atoms. The $\mathrm{C}_{5} \mathrm{H}_{5}$ ring on $\mathrm{Zn}(1)$ was refined with slack constraints on the bonds $\mathrm{C}(16)-\mathrm{C}(20)$ and $\mathrm{C}(17)-\mathrm{C}(18)$ in order to avoid an unsatisfactory ring geometry due to high thermal motion of some of the ring atoms. The refined parameter set included a scale factor, the coordinates of the non-hydrogen atoms, their anisotropic thermal parameters, and two separate isotropic temperature factors for the $\mathrm{H}$ atoms. Final positional parameters for the non-H atoms are listed in Table II. Scattering factors were taken from ref 10 and corrected for anomalous dispersion. ${ }^{11}$ The calculation of geometrical data and the preparation of illustrations were done with the programs PLATON and PLUTON of the EUCLID package. ${ }^{12}$

\section{Results and Discussion}

(a) Synthesis and NMR. When an equimolar mixture of $\mathrm{Zn}\left(\mathrm{C}_{5} \mathrm{H}_{5}\right)_{2}, \mathrm{Zn}\left(\mathrm{C}_{5} \mathrm{Me}_{5}\right)_{2}$, and $\mathrm{Ni}(\mathrm{COD})_{2}$ in benzene is

(6) De Boer, J. L.; Duisenberg, A. J. M. Acta Crystallogr. 1984, A40, C410.

(7) Walker, N.; Stuart, D. Acta Crystallogr. 1983, A39, 158.

(8) Sheldrick, G. M. SHELXs86, Program for Crystal Structure Determination; University of Göttingen, Göttingen: Federal Republic of Germany, 1986.

(9) Sheldrick, G. M. SHELx76, Crystal Structure Analysis Package; University of Cambridge: Cambridge, England, 1976.

(10) Cromer, D. T.; Mann, J. B. Acta Crystallogr. 1968, A24, 321

(11) Cromer, D. T.; Liberman, D. J. Chem. Phys. 1970, 53, 1891.

(12) Spek, A. L. The EUCLID Package. In Computational Crystallography; Sayre, D., Ed.; Clarendon Press: Oxford, 1982; p 528.
Table III. ${ }^{1} \mathrm{H}^{a}$ and ${ }^{13} \mathrm{C}^{b} \mathrm{NMR}$ Data of $\mathrm{Zn}_{4} \mathrm{Ni}_{2}\left(\mathrm{C}_{5} \mathrm{H}_{3}\right)_{\mathbf{2}}\left(\mathrm{C}_{8} \mathrm{Me}_{3}\right)_{2}{ }^{\mathrm{c}}$

\begin{tabular}{lllll}
\hline & solv & $\delta\left(\mathrm{C}_{5} \mathrm{H}_{5}-\mathrm{Zn}\right)$ & $\delta\left(\mathrm{C}_{5} \mathrm{H}_{5}-\mathrm{Ni}\right)$ & $\delta\left(\mathrm{C}_{5} \mathrm{Me}_{5}-\mathrm{Zn}\right)$ \\
\hline${ }^{1} \mathrm{H}$ & $\mathrm{C}_{6} \mathrm{D}_{6}$ & $6.40(\mathrm{~s}, 5 \mathrm{H})$ & $4.89(\mathrm{~s}, 5 \mathrm{H})$ & $2.11(\mathrm{~s}, 15 \mathrm{H})$ \\
& $\mathrm{CDCl}_{3}$ & $6.36(\mathrm{~s}, 5 \mathrm{H})$ & $4.93(\mathrm{~s}, 5 \mathrm{H})$ & $2.15(\mathrm{~s}, 15 \mathrm{H})$ \\
${ }^{13} \mathrm{C}$ & $\mathrm{C}_{6} \mathrm{D}_{6}$ & 106.88 & 85.56 & $114.21,11.96$ \\
& $\mathrm{CDCl}_{3}$ & 106.60 & 85.26 & $114.13,11.68$
\end{tabular}

${ }^{a} 200 \mathrm{MHz} .{ }^{b} 50.2 \mathrm{MHz} .{ }^{c}$ At $20^{\circ} \mathrm{C}, \delta$ in ppm relative to $\mathrm{SiMe}_{4}$; $=$ singlet.

heated for $7 \mathrm{~h}$ immediately after combining the reagents, two different clusters are formed, i.e. $\mathrm{Zn}_{4} \mathrm{Ni}_{2}\left(\mathrm{C}_{5} \mathrm{H}_{5}\right)_{6}$ and $\mathrm{Zn}_{4} \mathrm{Ni}_{2}\left(\mathrm{C}_{5} \mathrm{H}_{5}\right)_{4}\left(\mathrm{C}_{5} \mathrm{Me}_{5}\right)_{2}$ in a $3: 7$ ratio in a total yield of $75 \%$.

When, however, the reaction mixture is first stirred at room temperature for $24 \mathrm{~h}$ and then heated to $70^{\circ} \mathrm{C}$ for $5 \mathrm{~h}$, the mixed-metal, mixed-ligand cluster compound $\mathrm{Zn}_{4} \mathrm{Ni}_{2}\left(\mathrm{C}_{5} \mathrm{H}_{5}\right)_{4}\left(\mathrm{C}_{5} \mathrm{Me}_{5}\right)_{2}$ is formed exclusively and can be isolated as a dark green crystalline solid in $74 \%$ yield. In both reactions, the balance of metals was recovered as metallic zinc and nickel and traces of nickelocene. During the initial stages of the reaction at room temperature, the color of the reaction mixture slowly changes from yellow via orange to red and only upon heating is the dark green product formed. These two reactions are summarized in Scheme I.

The yield of the second reaction, surprisingly, is even higher than that of $\mathrm{Zn}_{4} \mathrm{Ni}_{2}\left(\mathrm{C}_{5} \mathrm{H}_{5}\right)_{6}(67 \%)$, which is obtained from the reaction of $\mathrm{Zn}\left(\mathrm{C}_{5} \mathrm{H}_{5}\right)_{2}$ with $\mathrm{Ni}(\mathrm{COD})_{2}$, and contrasts sharply with earlier results which showed that the introduction of even a single substituent on the cyclopentadienyl rings in the zinc starting material reduced the $\mathrm{Zn}_{4} \mathrm{Ni}_{2}$ cluster yield dramatically (yield of $\mathrm{Zn}_{4} \mathrm{Ni}_{2}\left(\mathrm{C}_{5} \mathrm{H}_{4} \mathrm{R}\right)_{6}$ for $\mathrm{R}=\mathrm{Me}(30 \%), t-\mathrm{Bu}(12 \%)$, and $\left.\mathrm{SiMe}_{3}(11 \%)\right)$. $\mathrm{Fi}-$ nally, the reaction of $\mathrm{Zn}\left(\mathrm{C}_{5} \mathrm{Me}_{5}\right)_{2}$ with $\mathrm{Ni}(\mathrm{COD})_{2}$ yielded no cluster at all. ${ }^{3}$

$\mathrm{Zn}_{4} \mathrm{Ni}_{2}\left(\mathrm{C}_{5} \mathrm{H}_{5}\right)_{4}\left(\mathrm{C}_{5} \mathrm{Me}_{5}\right)_{2}$, which is very air- and moisture-sensitive, was identified by means of elemental microanalysis and NMR spectroscopy (see Table III).

The ${ }^{1} \mathrm{H}$ NMR spectrum of the cluster contains three sharp singlets, in a ratio of $1: 1: 3$, that were assigned by comparison with the data for $\mathrm{Zn}_{4} \mathrm{Ni}_{2}\left(\mathrm{C}_{5} \mathrm{H}_{5}\right)_{6}{ }^{2}$ and $\mathrm{Zn}$ $\left(\mathrm{C}_{5} \mathrm{Me}_{5}\right)_{2}{ }^{4}$ to two zinc-bonded cyclopentadienyl groups, two nickel-bonded cyclopentadienyl groups, and two zincbonded pentamethylcyclopentadienyl groups, respectively, i.e. corresponding to the formulation $\left[\left(\mathrm{ZnC}_{5} \mathrm{Me}_{5}\right)_{2}\right.$ $\left.\left(\mathrm{ZnC}_{5} \mathrm{H}_{5}\right)_{2}\left(\mathrm{NiC}_{5} \mathrm{H}_{5}\right)_{2}\right]$. The ${ }^{13} \mathrm{C}$ spectrum showed the expected four signals, one for each of the different cyclopentadienyl ligands and two for the pentamethylcyclopentadienyl system.

On the basis of the structural features of $\mathrm{Zn}_{4} \mathrm{Ni}_{2}\left(\mathrm{C}_{5} \mathrm{H}_{5}\right)_{6}$ the substitution of two of the cyclopentadienyl groups in the already rather crowded cluster by two pentamethylcyclopentadienyl ligands was expected to have major effects on the coordination sphere of the metal octahedron. In order to study this in detail an X-ray crystal structure study on this new cluster was carried out.

(b) Crystal Structure of $\mathrm{Zn}_{4} \mathbf{N i}_{2}\left(\mathrm{C}_{5} \mathrm{H}_{5}\right)_{4}\left(\mathrm{C}_{5} \mathbf{M e}_{5}\right)_{2}$. The structure consists of the packing of two discrete molecules in a monoclinic unit cell. The molecular structure together with the adopted numbering scheme is given in Figure 2, and bonding distances and bond angles are presented in Table IV. 
Table IV. Selected Geometrical Data ${ }^{a}$

\begin{tabular}{ll}
\hline $\mathrm{Zn}(1)-\mathrm{Zn}(2)$ & $2.886(3)$ \\
$\mathrm{Zn}(1)-\mathrm{Zn}\left(2^{\prime}\right)$ & $2.901(3)$ \\
$\mathrm{Zn}(1)-\mathrm{Ni}$ & $2.433(3)$ \\
$\mathrm{Zn}(1)-\mathrm{Ni}\left({ }^{\prime}\right)$ & $2.370(3)$ \\
$\mathrm{Zn}(1)-\mathrm{C}(18)$ & $2.48(2)$ \\
$\mathrm{Zn}(1)-\mathrm{C}(19)$ & $2.21(2)$ \\
$\mathrm{Zn}(1)-\mathrm{C}(20)$ & $2.22(2)$ \\
$\mathrm{Zn}(2)-\mathrm{Ni}$ & $2.390(3)$ \\
$\mathrm{Zn}(2)-\mathrm{Ni}\left({ }^{\prime}\right)$ & $2.450(3)$ \\
$\mathrm{Zn}(2)-\mathrm{C}(9)$ & $2.24(1)$ \\
$\mathrm{Zn}(2)-\mathrm{C}(10)$ & $2.18(1)$ \\
$\mathrm{Ni}-\mathrm{Ni}\left({ }^{\prime}\right)$ & $2.551(3)$ \\
$\mathrm{Ni}-\mathrm{C}(1)$ & $2.11(2)$
\end{tabular}

$$
\begin{aligned}
& \mathrm{Zn}(2)-\mathrm{Zn}(1)-\mathrm{Zn}\left(2^{\prime}\right) \\
& \mathrm{Zn}(2)-\mathrm{Zn}(1)-\mathrm{Ni} \\
& \mathrm{Zn}(2)-\mathrm{Zn}(1)-\mathrm{Ni}\left(^{\prime}\right) \\
& \mathrm{Zn}\left(2^{\prime}\right)-\mathrm{Zn}(1)-\mathrm{Ni} \\
& \mathrm{Ni}-\mathrm{Zn}(1)-\mathrm{Ni}\left({ }^{\prime}\right) \\
& \mathrm{Zn}(1)-\mathrm{Ni}\left({ }^{\prime}\right)-\mathrm{Zn}(2) \\
& \mathrm{Zn}(1)-\mathrm{Ni}\left({ }^{\prime}\right)-\mathrm{Ni} \\
& \mathrm{Zn}(2)-\mathrm{Ni}\left({ }^{\prime}\right)-\mathrm{Ni} \\
& \mathrm{Zn}(1)-\mathrm{Zn}(2)-\mathrm{Zn}\left(1^{\prime}\right) \\
& \mathrm{Zn}(1)-\mathrm{Zn}(2)-\mathrm{Ni} \\
& \mathrm{C}(2)-\mathrm{C}(1)-\mathrm{C}(5) \\
& \mathrm{C}(1)-\mathrm{C}(2)-\mathrm{C}(3) \\
& \mathrm{C}(2)-\mathrm{C}(3)-\mathrm{C}(4) \\
& \mathrm{C}(3)-\mathrm{C}(4)-\mathrm{C}(5) \\
& \mathrm{C}(1)-\mathrm{C}(5)-\mathrm{C}(4) \\
& \mathrm{C}(7)-\mathrm{C}(6)-\mathrm{C}(10) \\
& \mathrm{C}(7)-\mathrm{C}(6)-\mathrm{C}(11) \\
& \mathrm{C}(10)-\mathrm{C}(6)-\mathrm{C}(11) \\
& \mathrm{C}(6)-\mathrm{C}(7)-\mathrm{C}(8) \\
& \mathrm{C}(6)-\mathrm{C}(7)-\mathrm{C}(12) \\
& \mathrm{C}(8)-\mathrm{C}(7)-\mathrm{C}(12) \\
& \mathrm{C}(7)-\mathrm{C}(8)-\mathrm{C}(9) \\
& \mathrm{C}(7)-\mathrm{C}(8)-\mathrm{C}(13)
\end{aligned}
$$

$2.886(3)$

(3)

$370(3)$

$.48(2)$

$21(2)$

$.22(2)$

$390(3)$

(3)

$18(1)$

$.11(2)$

(1)

These

\begin{tabular}{ll}
\multicolumn{2}{c}{ (a) Bond Distances $(\AA)$} \\
$\mathrm{Ni}-\mathrm{C}(2)$ & $2.10(1)$ \\
$\mathrm{Ni}-\mathrm{C}(3)$ & $2.09(2)$ \\
$\mathrm{Ni}-\mathrm{C}(4)$ & $2.06(1)$ \\
$\mathrm{Ni}-\mathrm{C}(5)$ & $2.07(2)$ \\
$\mathrm{C}(1)-\mathrm{C}(2)$ & $1.41(3)$ \\
$\mathrm{C}(1)-\mathrm{C}(5)$ & $1.37(3)$ \\
$\mathrm{C}(2)-\mathrm{C}(3)$ & $1.38(2)$ \\
$\mathrm{C}(3)-\mathrm{C}(4)$ & $1.38(3)$ \\
$\mathrm{C}(4)-\mathrm{C}(5)$ & $1.35(3)$ \\
$\mathrm{C}(6)-\mathrm{C}(7)$ & $1.37(2)$ \\
$\mathrm{C}(6)-\mathrm{C}(10)$ & $1.40(2)$ \\
$\mathrm{C}(6)-\mathrm{C}(11)$ & $1.50(2)$ \\
&
\end{tabular}

(b) Bond Angles (deg)

$\begin{array}{rlr}90.61(7) & \mathrm{Zn}(1)-\mathrm{Zn}(2)-\mathrm{Ni}\left({ }^{\prime}\right) & 51.94(7) \\ 52.55(7) & \mathrm{Zn}\left(1^{\prime}\right)-\mathrm{Zn}(2)-\mathrm{Ni} & 52.13(7) \\ 54.51(7) & \mathrm{Ni}-\mathrm{Zn}(2)-\mathrm{Ni}\left({ }^{\prime}\right) & 63.60(7) \\ 53.83(7) & \mathrm{Zn}(1)-\mathrm{Ni}-\mathrm{Zn}\left(1^{\prime}\right) & 115.86(9) \\ 64.14(7) & \mathrm{Zn}(1)-\mathrm{Ni}-\mathrm{Zn}(2) & 73.51(8) \\ 73.54(8) & \mathrm{Zn}(1)-\mathrm{Ni}-\mathrm{Zn}\left(2^{\prime}\right) & 72.87(8) \\ 59.14(7) & \mathrm{Zn}(1)-\mathrm{Zn}\left(2^{\prime}\right)-\mathrm{Ni} & 53.29(7) \\ 57.04(7) & \mathrm{Zn}\left(1^{\prime}\right)-\mathrm{Ni}-\mathrm{Zn}(2) & 75.11(8) \\ 89.39(7) & \mathrm{Zn}(2)-\mathrm{Ni}-\mathrm{Zn}\left(2^{\prime}\right) & 116.40(8) \\ 53.94(7) & \mathrm{Zn}(2)-\mathrm{Zn}\left(1^{\prime}\right)-\mathrm{Ni} & 52.76(7) \\ 106(2) & \mathrm{C}(9)-\mathrm{C}(8)-\mathrm{C}(13) & 124(1) \\ 108(1) & \mathrm{C}(8)-\mathrm{C}(9)-\mathrm{C}(10) & 104(1) \\ 107(2) & \mathrm{C}(8)-\mathrm{C}(9)-\mathrm{C}(14) & 128(1) \\ 109(2) & \mathrm{C}(10)-\mathrm{C}(9)-\mathrm{C}(14) & 127(1) \\ 110(2) & \mathrm{C}(6)-\mathrm{C}(10)-\mathrm{C}(9) & 107(1) \\ 109(1) & \mathrm{C}(6)-\mathrm{C}(10)-\mathrm{C}(15) & 125(1) \\ 125(1) & \mathrm{C}(9)-\mathrm{C}(10)-\mathrm{C}(15) & 126(1) \\ 126(1) & \mathrm{C}(17)-\mathrm{C}(16)-\mathrm{C}(20) & 101(2) \\ 109(1) & \mathrm{C}(16)-\mathrm{C}(17)-\mathrm{C}(18) & 116(3) \\ 127(1) & \mathrm{C}(17)-\mathrm{C}(18)-\mathrm{C}(19) & 106(2) \\ 125(1) & \mathrm{C}(18)-\mathrm{C}(19)-\mathrm{C}(20) & 104(2) \\ 110(1) & \mathrm{C}(16)-\mathrm{C}(20)-\mathrm{C}(19) & 111(2) \\ 126(1) & & \end{array}$

$\begin{array}{ll}\mathrm{C}(7)-\mathrm{C}(8) & 1.37(2) \\ \mathrm{C}(7)-\mathrm{C}(12) & 1.53(2) \\ \mathrm{C}(8)-\mathrm{C}(9) & 1.41(2) \\ \mathrm{C}(8)-\mathrm{C}(13) & 1.53(2) \\ \mathrm{C}(9)-\mathrm{C}(10) & 1.47(2) \\ \mathrm{C}(9)-\mathrm{C}(14) & 1.46(2) \\ \mathrm{C}(10)-\mathrm{C}(15) & 1.50(2) \\ \mathrm{C}(16)-\mathrm{C}(17) & 1.25(4) \\ \mathrm{C}(16)-\mathrm{C}(20) & 1.35(4) \\ \mathrm{C}(17)-\mathrm{C}(18) & 1.33(4) \\ \mathrm{C}(18)-\mathrm{C}(19) & 1.30(4) \\ \mathrm{C}(19)-\mathrm{C}(20) & 1.38(4)\end{array}$

a Symmetry code: the prime $\left({ }^{\prime}\right)=1-x, 1-y,-z$.

The molecular structure comprises a $\mathrm{Zn}_{4} \mathrm{Ni}_{2}$ octahedron with the two nickel atoms occupying apical sites. This metal core is coordinated by four cyclopentadienyl ligands, of which two are zinc- and two are nickel-bonded, and by two zinc-bonded pentamethylcyclopentadienyl ligands. The regularity of the metal octahedron is well illustrated by the $\mathrm{Zn}-\mathrm{Zn}-\mathrm{Zn}$ bond angles which are very close to $90^{\circ}$, i.e. ranging from 89.39 (7) to $90.61(7)^{\circ}$. Moreover, all $\mathrm{Zn}-\mathrm{Ni}$ distances are similar, falling in the range 2.370 (3)-2.450 (3) $\AA$. The distance between the apical Ni atoms amounts to 2.551 (3) $\AA$.

It is of interest to compare the molecular structures of $\mathrm{Zn}_{4} \mathrm{Ni}_{2}\left(\mathrm{C}_{5} \mathrm{H}_{5}\right)_{4}\left(\mathrm{C}_{5} \mathrm{Me}_{5}\right)_{2}$ and $\mathrm{Zn}_{4} \mathrm{Ni}_{2}\left(\mathrm{C}_{5} \mathrm{H}_{5}\right)_{6}$.

The exchange of two cyclopentadienyl ligands for two, more electron-donating, pentamethylcyclopentadienyl ligands affects the geometry of the metal core to only a small extent. In first instance this might seem surprising, but it is consistent with calculations carried out by Budzelaar et al., who showed that the highest molecular orbitals of the parent $\mathrm{Zn}_{4} \mathrm{Ni}_{2}\left(\mathrm{C}_{5} \mathrm{H}_{5}\right)_{6}$ cluster are almost pure ligand orbitals. ${ }^{1}$ In the present cluster a relative lengthening of the $\mathrm{Zn}-\mathrm{Ni}$ and $\mathrm{Zn}-\mathrm{Zn}$ distances together with a shortening of the Ni-Ni distance is found. This JahnTeller-like distortion is indicative of the somewhat higher electron density in the metal core. ${ }^{13}$

The $\eta^{5}$-coordination of the nickel atoms by two cyclopentadienyl ligands is retained in the present structure; this was also observed in the $\mathrm{Zn}_{4} \mathrm{Ni}_{2}\left(\mathrm{C}_{5} \mathrm{H}_{4} \mathrm{R}\right)_{6}$ clusters and seems to be a common feature when $\mathrm{C}_{5} \mathrm{H}_{5}$ groups are substituted by $\mathrm{C}_{5} \mathrm{H}_{4} \mathrm{R}$ or $\mathrm{C}_{5} \mathrm{Me}_{5}$ groups. In $\mathrm{Zn}_{4} \mathrm{Ni}_{2^{-}}$

(13) Paquette, M. S.; Dahl, L. F. J. Am. Chem. Soc. 1980, 120, 6623.

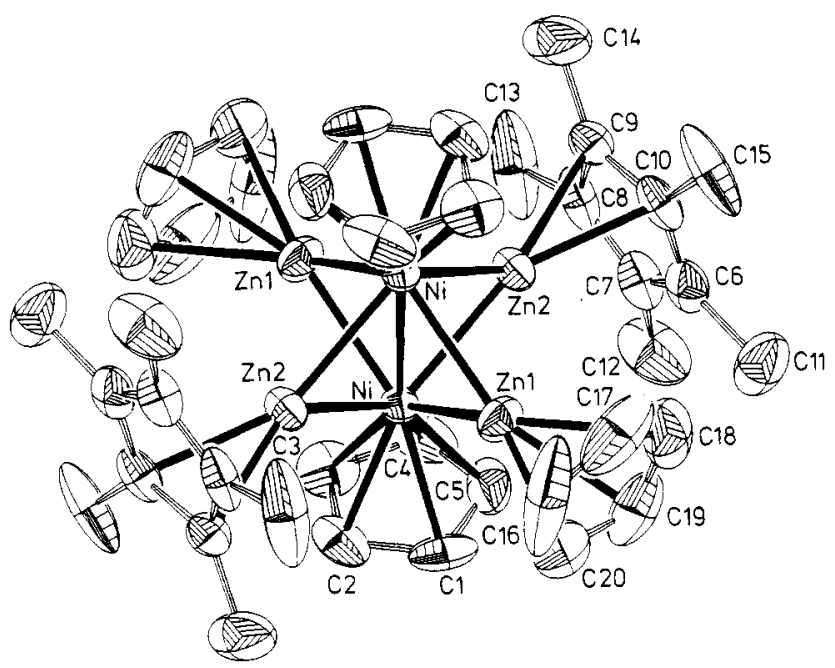

Figure 2. Thermal motion ellipsoid plot (scaled to $30 \%$ probability) of $\mathrm{Zn}_{4} \mathrm{Ni}_{2}\left(\mathrm{C}_{5} \mathrm{H}_{5}\right)_{4}\left(\mathrm{C}_{5} \mathrm{Me}_{5}\right)_{2}$ with the adopted numbering. $\mathrm{H}$ atoms have been omitted.

$\left(\mathrm{C}_{5} \mathrm{H}_{5}\right)_{4}\left(\mathrm{C}_{5} \mathrm{Me}_{5}\right)_{2}$ the mean $\mathrm{Ni}-\mathrm{C}$ distance is somewhat shorter than in $\mathrm{Zn}_{4} \mathrm{Ni}_{2}\left(\mathrm{C}_{5} \mathrm{H}_{5}\right)_{6}(2.087$ (16) vs $2.12 \AA$ ) and the bonding is even more symmetrical; all nickel-ring carbon distances are equal within the esd, and there is negligible ring slippage of the nickel-bonded cyclopentadienyl ring $(0.036 \AA)$. (The ring slippage is defined as the distance between the ring centroid and the perpendicular projection of the metal atom on the leastsquares plane.) The nickel-bonded cyclopentadienyl ring itself is almost perfectly symmetrical. The ring is flat, all 


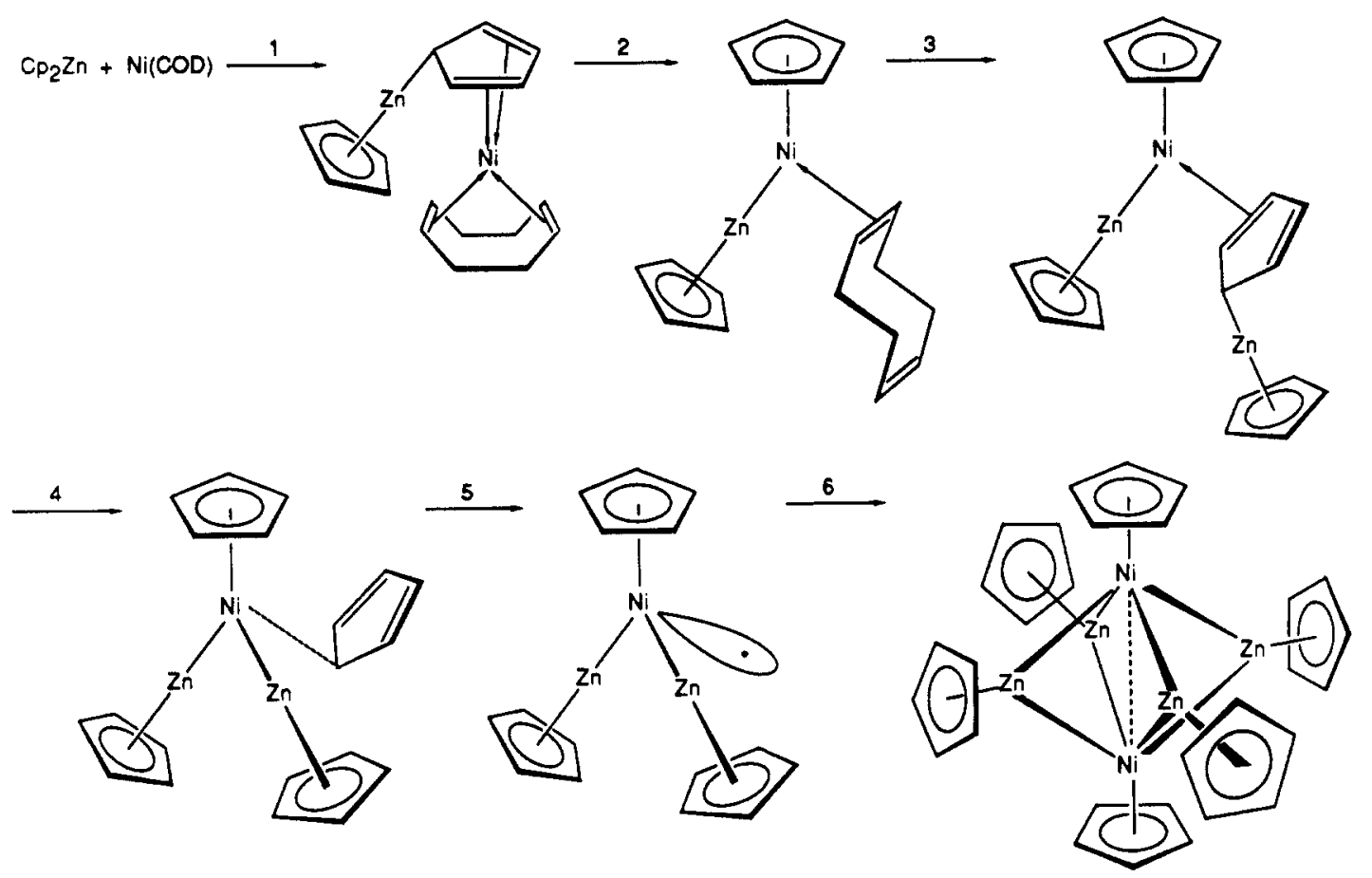

Figure 3. Part of the general reaction mechanism, proposed for the reaction of bis(cyclopentadienyl)zinc compounds with $\mathrm{Ni}(\mathrm{COD})_{2}$.

$\mathrm{C}-\mathrm{C}$ distances are equal within the esd (1.38 (2) $\AA$ ), and the bond angles within the ring differ only little; i.e., they range from $106.2(15)$ to $109.9(16)^{\circ}$.

Profound differences are found in the zinc-cyclopentadienyl bonding. Whereas in the $\mathrm{Zn}_{4} \mathrm{Ni}_{2}\left(\mathrm{C}_{5} \mathrm{H}_{5}\right)_{6}$ cluster symmetrical $\eta^{5}$-bonding occurs (mean $\mathrm{Zn}-\mathrm{C}$ distance $=2.36 \AA)$, in the title compound two short $(2.209$ (19) and $2.220(20) \AA$ ) and three longer (2.48 (2), 2.52 (3), and 2.67 (2) $\AA$ ) $\mathrm{Zn}-\mathrm{C}$ bonds are present. This latter bonding arrangement is best described as being intermediate between $\eta^{2}$ - and $\eta^{3}$-coordination $\left(\eta^{3}\right.$-coordination requires one short, two intermediate, and two long distances, as found in $\mathrm{Zn}_{4} \mathrm{Ni}_{2}\left(\mathrm{C}_{5} \mathrm{H}_{4} \mathrm{SiMe}_{3}\right)_{6}$, whereas $\eta^{2}$-coordination requires two short, two longer and one very long distance).

An exact assessment based on a geometrical evaluation is impossible because in the present structure the zincbonded cyclopentadienyl rings show large thermal motions. However, when the zinc-bonded cyclopentadienyl ring is compared with the nickel-bonded cyclopentadienyl ring, some significant differences are apparent: the zinc-bonded ring is asymmetric and not flat, as is shown by the differences in the bond lengths (ranging from 1.25 (4) to 1.38 (4) $\AA$ ) and bond angles (ranging from $101(2)$ to $116(3)^{\circ}$ ). Also the ring slippage of $0.594 \AA$ points to an asymmetric bonding mode.

The bonding of the pentamethylcyclopentadienyl group to zinc can be better established on the basis of the ring geometries and indicates $\mathrm{Zn}_{4} \mathrm{Ni}_{2}\left(\mathrm{C}_{5} \mathrm{H}_{5}\right)_{4}\left(\mathrm{C}_{5} \mathrm{Me}_{5}\right)_{2}$ to be the first clear example of an $\eta^{2}$-coordination mode for a cyclopentadienyl ligand to a main-group metal. When the $\mathrm{C}_{5} \mathrm{Me}_{5}-\mathrm{Zn}$ bonding distances in this cluster are compared to those encountered in crystalline $\mathrm{Zn}\left(\mathrm{C}_{5} \mathrm{Me}_{5}\right)_{2}\left(\eta^{5}\right.$, mean $\left.2.29 \AA ; \eta^{1}, 2.09 \AA\right),{ }^{14}$ there are two short, $2.180(13)$ and 2.244 (13) $\AA$, two longer, 2.556 (14) and 2.589 (15) $\AA$, and one very long, 2.817 (14) $\AA, \mathrm{Zn}-\mathrm{C}$ distance which points to $\eta^{2}$-bonding. The fact that only two carbon atoms of the pentamethylcyclopentadienyl ring interact with zinc is also indicated by the angles which the $\mathrm{C}_{\mathrm{Me}}-\mathrm{C}_{\text {ring }}$ bonds make

(14) Fischer, B.; Wijkens, P.; Boersma, J.; van Koten, G.; Smeets, W. J. J.; Spek, A. L., submitted for publication in Organometallics. with the ring plane. Small angles, i.e. $1.4,2.5$, and $4.0^{\circ}$, pointing away from the metal, are found for the three nonbonded carbon atoms while these angles for the other two carbon atoms are larger, i.e. 9.9 and $10.5^{\circ}$.

The $\eta^{2}$-bonding mode obviously does not change the ring symmetry itself to a large extent; the pentamethylcyclopentadienyl ring is more symmetrical than the unsubstituted zinc-bonded ring; relative small differences in bond distances (ranging from $1.370(20)$ to $1.468(20) \AA$ ) and bond angles (ranging from $104.4(11)$ to $110.3(13)^{\circ}$ ) occur. This is in accord with a predominantly ionic character of the $\mathrm{Zinc}-\mathrm{C}_{5} \mathrm{Me}_{5}$ interaction like that found in solid $\mathrm{Zn}$ $\left(\mathrm{C}_{5} \mathrm{Me}_{5}\right)_{2}$ and $\mathrm{Zn}\left(\mathrm{C}_{5} \mathrm{Me}_{4} \mathrm{C}_{6} \mathrm{H}_{5}\right)_{2}{ }^{14}$ Finally, the ring slippage of $0.718 \AA$ of the pentamethylcyclopentadienyl ring is larger than that of the $\eta^{2}-\eta^{3}$ bonded cyclopentadienyl ring and is indicative of an even more acentric bonding of the $\mathrm{C}_{5} \mathrm{Me}_{5}$ ring to zinc.

(c) The Cluster Formation Mechanism. The formation of $\mathrm{Zn}_{4} \mathrm{Ni}_{2}\left(\mathrm{C}_{5} \mathrm{H}_{5}\right)_{4}\left(\mathrm{C}_{5} \mathrm{Me}_{5}\right)_{2}$ as well as the different results from the two synthetic experiments, shown in Scheme I, provide further support for the mechanism proposed recently for the formation of the cluster compounds of the type $\mathrm{Zn}_{4} \mathrm{Ni}_{2}\left(\mathrm{C}_{5} \mathrm{H}_{4} \mathrm{R}\right)_{6}$ (Figure 3). Moreover, the selectivity observed for the formation of the title compound enabled us to identify the rate-determining step in these cluster-forming reactions.

From a detailed analysis of the experimental results it is now possible to conclude that the initial step in the reaction is attack by $\mathrm{Zn}\left(\mathrm{C}_{5} \mathrm{H}_{5}\right)_{2}$ at the reactive 14-electron species $\mathrm{Ni}(\mathrm{COD})$, which is formed by dissociation of $\mathrm{Ni}$ $(\mathrm{COD})_{2}$.

This deduction is based on the fact that among the reaction products no $\mathrm{C}_{5} \mathrm{Me}_{5}$ rings bonded to nickel occur. If initial attack had been by $\mathrm{Zn}\left(\mathrm{C}_{5} \mathrm{Me}_{5}\right)_{2}$ the second reaction step, i.e. insertion of nickel into the $\mathrm{Zn}-\mathrm{C}_{5} \mathrm{Me}_{5}$ bond, would have resulted in a species with a $\mathrm{Ni}-\mathrm{C}_{5} \mathrm{Me}_{5}$ bond. Similarly, initial attack of a third possible species, $\mathrm{Zn}$ $\left(\mathrm{C}_{5} \mathrm{H}_{5}\right)\left(\mathrm{C}_{5} \mathrm{Me}_{5}\right)$, which might be present as a result of a prior comproportionation reaction of $\mathrm{Zn}\left(\mathrm{C}_{5} \mathrm{H}_{5}\right)_{2}$ with $\mathrm{Zn}$ $\left(\mathrm{C}_{5} \mathrm{Me}_{5}\right)_{2}$, can be ruled out. When $\mathrm{Zn}\left(\mathrm{C}_{5} \mathrm{H}_{5}\right)\left(\mathrm{C}_{5} \mathrm{Me}_{5}\right)$ would have been involved in the first reaction step, additional 
clusters like $\left[\mathrm{Zn}_{4}\left(\mathrm{C}_{5} \mathrm{H}_{5}\right)_{4} \mathrm{Ni}_{2}\left(\mathrm{C}_{5} \mathrm{Me}_{5}\right)_{2}\right]$ and, less probably, $\left[\mathrm{Zn}_{2}\left(\mathrm{C}_{5} \mathrm{Me}_{5}\right) \mathrm{Zn}_{2}\left(\mathrm{C}_{5} \mathrm{H}_{5}\right)_{2} \mathrm{Ni}_{2}\left(\mathrm{C}_{5} \mathrm{Me}_{5}\right)_{2}\right]$ should have been formed and the formation of $\mathrm{Zn}_{4} \mathrm{Ni}_{2}\left(\mathrm{C}_{5} \mathrm{H}_{5}\right)_{6}$ could not be accounted for.

The rate-determining step in the cluster formation reaction is the nickel insertion in step 2. This is deduced from the following facts. First, although a reaction already takes place at room temperature, cluster formation is only observed after a period of heating and therefore step 1 is not rate-determining. Second, the reaction that involved heating of the reaction mixture after a 24 -h room-temperature reaction period results in the exclusive formation of the mixed product $\mathrm{Zn}_{4} \mathrm{Ni}_{2}\left(\mathrm{C}_{5} \mathrm{H}_{5}\right)_{4}\left(\mathrm{C}_{5} \mathrm{Me}_{5}\right)_{2}$. This indicates that the rate-determining step is prior to step 3 , which is the displacement of a second COD molecule by an organozinc species. If the rate-determining step would follow step 3, this displacement could also be accomplished, instead of by $\mathrm{Zn}\left(\mathrm{C}_{5} \mathrm{Me}_{5}\right)_{2}$, by some - still unreacted-more reactive $\mathrm{Zn}\left(\mathrm{C}_{5} \mathrm{H}_{5}\right)_{2}$. This would, however, lead to the formation of the symmetric $\mathrm{Zn}_{4} \mathrm{Ni}_{2}\left(\mathrm{C}_{5} \mathrm{H}_{5}\right)_{6}$ cluster. This particular postulate was confirmed by the result from the reaction carried out without initial room-temperature stirring. In this case the rates of the various steps become comparable, and then $\mathrm{Zn}\left(\mathrm{C}_{5} \mathrm{H}_{5}\right)_{2}$ can indeed compete with $\mathrm{Zn}\left(\mathrm{C}_{5} \mathrm{Me}_{5}\right)_{2}$ in step 3 and formation of $\mathrm{Zn}_{4} \mathrm{Ni}_{2}\left(\mathrm{C}_{5} \mathrm{H}_{5}\right)_{2}$ does also occur. The high yield of $\mathrm{Zn}_{4} \mathrm{Ni}_{2}\left(\mathrm{C}_{5} \mathrm{H}_{5}\right)_{4}\left(\mathrm{C}_{5} \mathrm{Me}_{5}\right)_{2}$ in the reaction with initial stirring at room temperature also points to the exclusion of step 3 as rate determining. If this was not the case, a lower yield or the mixed-metal, mixed-ligand cluster, when compared to the reaction of $\mathrm{Zn}\left(\mathrm{C}_{5} \mathrm{H}_{5}\right)_{2}$ and $\mathrm{Ni}(\mathrm{COD})_{2}$, would be expected from a step in which the bulky $\mathrm{Zn}\left(\mathrm{C}_{5} \mathrm{Me}_{5}\right)_{2}$ species must react.

The high yield with which the new cluster can be isolated can be ascribed to the stabilizing influence of the $\mathrm{C}_{5} \mathrm{Me}_{5}$ ligand on the $\mathrm{Zn}_{2} \mathrm{Ni}\left(\mathrm{C}_{5} \mathrm{H}_{5}\right)_{2}\left(\mathrm{C}_{5} \mathrm{Me}_{5}\right)$ radical formed in step 5. Compared to reactions involving other cyclopentadienyl systems, this permethyl ligand appears to decrease the amount of decomposition of this type of trimetallic species.

Acknowledgment. D. M. Grove is thanked for his interest and for the very helpful discussions during the preparation of the manuscript. G. P. M. van Mier is kindly acknowledged for the isolation of a suitable single-crystal. X-ray data were collected by A. J. M. Duisenberg. This work was supported in part (A.L.S.) by the Netherlands Foundation for Chemical Research (SON) with financial aid from the Netherlands Organization for Scientific Research (NWO).

Supplementary Material Available: Listings of hydrogen atom positions, thermal parameters, bond distances, and bond angles involving hydrogen atoms (7 pages); a listing of the $F_{\circ}$ and $F_{\mathrm{c}}$ values (12 pages). Ordering information is given on any current masthead page.

\title{
Reaction of Triphenylphosphine with the Anionic Cluster $\left[\mathrm{HRu}_{3}(\mathrm{CO})_{11}\right]^{-}$Revisited: Isolation, Crystal Structure, and Isomerization of $\left[\mathrm{NEt}_{4}\right]\left[\mathrm{HRu}_{3}(\mathrm{CO})_{8}\left(\mathrm{PPh}_{3}\right)\left(\mathrm{PPhC}_{6} \mathrm{H}_{4}\right)\right]$
}

\author{
Hubert Jungbluth and Georg Süss-Fink*,1 \\ Institut für Anorganische Chemie der Rheinisch-Westfälischen Technischen Hochschule Aachen, \\ Templergraben 55, D-5100 Aachen, FRG \\ Maria Angela Pellinghelli and Antonio Tiripicchio* \\ Istituto di Chimica Generale ed Inorganica, Centro di Studio per la Strutturistica Diffrattometrica del CNR, \\ Università di Parma, Viale delle Scienze, I-43100 Parma, Italy
}

Received July 26, 1988

\begin{abstract}
The reaction of the cluster anion $\left[\mathrm{HRu}_{3}(\mathrm{CO})_{11}\right]^{-}$with $\mathrm{PPh}_{3}$ in refluxing THF results in the formation of the orthometalation product $\left[\mathrm{HRu}_{3}(\mathrm{CO})_{8}\left(\mathrm{PPh}_{3}\right)\left(\mathrm{PPhC}_{6} \mathrm{H}_{4}\right)\right]^{-}(3)$. The cluster anions $\left[\mathrm{HRu}_{3}(\mathrm{CO})_{10}\left(\mathrm{PPh}_{3}\right)\right]^{-}$ (1) and $\left[\mathrm{Ru}_{3}(\mathrm{CO})_{9}\left(\mathrm{PPh}_{3}\right)\right]^{2-}(2)$ are supposed to be intermediates in this reaction. The protonation of 3 yields the neutral cluster $\mathrm{H}_{2} \mathrm{Ru}_{3}(\mathrm{CO})_{8}\left(\mathrm{PPh}_{3}\right)\left(\mathrm{PPhC}_{6} \mathrm{H}_{4}\right)(4)$; however, the deprotonation of 4 with potassium selectride gives anion $\mathbf{5}$, an isomer of $\mathbf{3}$, differing in the position of the hydride bridge. The structure of 3 was determined by a single-crystal $\mathrm{X}$-ray analysis of the tetraethylammonium salt. Crystals are monoclinic, space group $P 2_{1}$, with the unit-cell parameters $a=13.250$ (4) $\AA, b=14.467$ (4) $\AA, c=12.667$ (8) $\AA, \beta=$ $99.97(2)^{\circ}$, and $Z=2$. The structure was solved from diffractometer data by direct and Fourier methods and refined by full-matrix least squares to $R=0.0576$ and $R_{\mathrm{w}}=0.0697$ for 1339 observed reflections $[I$ $\geq 2 \sigma(I)]$. The longest edge of the triangular cluster is bridged by the hydride. The orthometalated phosphinidene ligand interacts with the three metal atoms: the phosphorus bridges two ruthenium atoms, while the third Ru atom is bonded to a carbon atom of the phosphinidene ligand.
\end{abstract}

\section{Introduction}

The reaction of the cluster anion $\left[\mathrm{HRu}_{3}(\mathrm{CO})_{11}\right]^{-}$with triphenylphosphine has been investigated in a detailed kinetic study by Ford et al. ${ }^{2,3}$ The kinetic data suggest

(1) New address: Institut de Chimie, Universitẻ de Neuchâtel, Avenue de Bellevaux 51, CH-2000 Neuchâtel, Suisse.

(2) Taube, D. J,; van Eldik, R.; Ford, P. C. Organometallics 1987, 6, $125-129$. the reversible formation of the monosubstitution product $\left[\mathrm{HRu}_{3}(\mathrm{CO})_{10}\left(\mathrm{PPh}_{3}\right)\right]^{-}(1)$. Although this anion was not $\left[\mathrm{HRu}_{3}(\mathrm{CO})_{11}\right]^{-}+\mathrm{PPh}_{3} \rightleftharpoons\left[\mathrm{HRu}_{3}(\mathrm{CO})_{10}\left(\mathrm{PPh}_{3}\right)\right]^{-}+\mathrm{CO}$ isolated, evidence for the existence of 1 in solution was provided by a ${ }^{1} \mathrm{H}$ NMR signal at $\delta-11.91 \mathrm{ppm}$ displaying

(3) Taube, D. J.; Ford, P. C. Organometallics 1986, 5, 99-104. 